\title{
Convergence with the IFRS - Benefits and Challenges for India
}

\section{Dr. Archana Bhatia}

Associate professor

Head, Department of Commerce

DAV Centenary College, Faridabad

\section{Abstract}

To present reports and information in a uniform and globalized way, it is essential for the companies to adopt International Financial Reporting Standards (IFRS). This is single set of accounting standards which are followed to present financial statements for the investors. In India, mainly GAAPs were used by companies to present financial statements. But the adoption of national accounting standards may complicate the process of comparison due to difference in accounting policies of different nations, so may create confusion for investors. That's why national accounting standards are converged to IFRS. This paper is an attempt to present the convergence of national standards to IFRS and how the benefits of adopting IFRS overwhelm the pain of convergence.

Key Words: IFRS, India, IAS, IFRIC

\section{Council for Innovative Research}

Peer Review Research Publishing System Journal: International Journal of Management \& Information Technology

Vol. 10 No. 3

editorsijmit@gmail.com

www.ijmit.com/ojs 


\section{Introduction}

In recent times, capital markets have become global and continue to expand. Moreover, there has been significant globalization of production and trade. Investors can trade shares and securities worldwide. Entities are in a position to access the funds globally in the most advantageous markets. For this, investors from all over the world rely upon financial statements before taking decisions. They need to be convinced that the financial statements are true and fair and what they understand from the statements is what the person preparing them intends to convey. However, different countries adopt different accounting treatments and disclosure patterns with respect to the same economic event. This may create confusion among the users while interpreting the financial statements. Financial statements that are based on a single, universally accepted and used GAAP will enable the world to exchange financial information in a meaningful and trustworthy manner. This will accelerate the globalization of finance.

\section{International Financial Reporting Standards}

IAS/IFRS is a single set of high quality, understandable and enforceable global accounting standards. It is a "principles based" set of standards which are drafted clearly and are easy to understand and apply.

International Financial Reporting Standards comprise of:

- International Financial Reporting Standards (IFRS) - standards issued after 2001

- International Accounting Standards (IAS) - standards issued before 2001

- Interpretations originated from the International Financial Reporting Interpretations Committee (IFRIC) - issued after 2001

- $\quad$ Standing Interpretations Committee (SIC) - issued before 2001

In addition to the above, there is a "Framework for the Preparation and Presentation of Financial Statements", which describes the principles underlying the IFRS.

\section{Convergence}

The two terms though used interchangeably but there is a faint, but important difference. Adoption- is process of adopting IFRS as issued by IASB, with or without modifications. Modifications being, generally in the nature of additional disclosures requirement or elimination of alternative treatment. It involves an endorsement of IFRS by legislative or regulatory with minor modifications done by standard setting authority of a country.

A financial statement of any company is prepared as per the guidelines of each country GAAPs. Indian GAAPs are different from US GAAPs or from Canada GAAPs and so on. In this globalised era, comparison of financial statements of these companies of different countries creates some confusion in the mind of investors or simply users. These companies are listed on stock exchanges across the globe and the difference in financial statements definitely creates confusion in the minds of investors and ultimately may affect market price of the stock of company. To remove this confusion and intricacy of business transactions in the era of globalization is must and answer to this is to have single set of world class standards for reporting financial statements for reporting financial and non financial information. This thought has prompted counties to follow convergence of national accounting standards to IFRSs. European Union countries, Russia, New Zealand, and Australia have already adopted IFRSs. China has adopted in 2008 and Canada will adopt from 2011.

\section{What is Convergence with reference to IFRS?}

Convergence in a simple term, it means achieving harmonization with IFRSs. In the Indian context we can say, to design and preserve the Indian GAAPs in such a way that Indian financial statements are prepared in accord with compliance of IFRS.

In a recent visit to India, Mr. Barack Obama, President of United States of America, in his speech at Indian Parliament said, "India is not a developing country, it is a developed country". Indian Companies have achieved tremendous growth in most of the sectors, may it be IT, ITES, automobiles, infrastructure, pharmacy and they have excelled in all these sectors nationally as well as internationally. So to make easy comparison with international entities, its better have common rules and regulations to prepare financial statements by all the companies of world.

\section{Need of convergence}

- Single set of accounting standard all over the world,

- It would be beneficial to regulators too, as a complexity associated with needing to understand various reporting regimes would be reduced.

- Compliance burden on the companies will be reduced as they didn't require preparing separate set of financial statement to comply with statutes of other states.

Applicability of IFRS as proposed by ICAI and reporting time: 


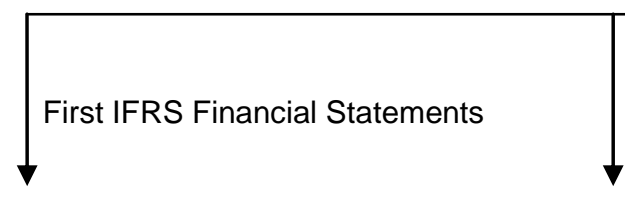

Date of Transition

April 1, 2010
March 31, 2011

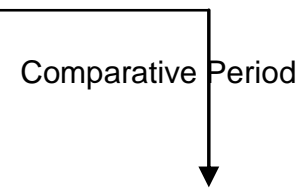

Reporting Date

March 31, 2012

On January 22, 2010, the Ministry of Corporate Affairs (MCA) issued a press release which laid out a phase wise IFRS convergence plan which will be achieved in India for companies other than Banking and Insurance Companies. According to the mentioned press release, there will be two separate sets of Accounting Standards under Section 211(3C) of the Companies Act, 1956. The two sets would be as described below:

- $\quad$ First Set would comprise of the Indian Accounting Standards which are converged with the IFRS (IFRS converged standards). It shall be applicable to specified class of companies;

- $\quad$ Second Set would comprise of the existing Indian Accounting Standards (Existing Accounting Standards) and would be applicable to other companies including small and medium companies (SMCs).

Applicability of First Set of Standards to Specified Class of Companies in Phase Manner

\begin{tabular}{|c|c|c|}
\hline Phase no. & Specified Class of Companies & Effective Date \\
\hline I & $\begin{array}{l}>\quad \text { Companies in Nifty } 50 \\
>\quad \text { Companies in Sensex } 30 \\
>\quad \text { Companies (whether listed or not) having } \\
\text { net worth in excess of Rs. } \\
>\quad 1,000 \text { crores } \\
>\quad \text { Companies having their shares or other } \\
\text { securities listed on stock exchanges outside } \\
\text { India }\end{array}$ & April 1, 2011 \\
\hline II & $\begin{array}{l}\text { Companies (whether listed or not) having net } \\
\text { worth in excess of Rs. } 500 \text { crores but less than } \\
\text { Rs. } 1,000 \text { crores }\end{array}$ & April 1, 2013 \\
\hline III & $\begin{array}{l}\text { All listed companies with net worth less than Rs. } \\
500 \text { crores }\end{array}$ & April 1, 2014 \\
\hline
\end{tabular}

The above enlisted specified class of companies will prepare an opening balance sheet in accordance with IFRS converged standards as of effective date and will follow the IFRS converged standards from the respective effective date.

On March 31, 2010, the Ministry of Corporate Affairs issued the final road map of Convergence with IFRS for Banking and Insurance Companies also.

- $\quad$ All scheduled commercial banks will converge effective April 1, 2013. A phased approach of convergence is prescribed for urban co-operative banks (UCBs).

- NBFC's which are part of Nifty - 50, Sensex 30 and NBFC's (listed or unlisted) having net worth of more than Rs. 1,000 crores will converge effective April 1, 2013.

- All other listed NBFC's and other NBFC's having a net worth in excess of Rs 500 crores would converge effective April 1, 2014.

- Unlisted NBFC's having a net worth of less than Rs 500 crores are not mandatorily required to converge but may voluntarily decide to converge.

- $\quad$ All insurance companies will converge with Converged Indian accounting standards effective April 1, 2012.

- IFRSs would not be applicable for- (a) Unlisted companies which have a net worth of Rs. 500 crores or less and whose shares or other securities are not listed on stock exchanges outside India and (b) SMEs. 


\title{
Change in Key Accounting Policies \& Procedures
}

The adoption of IFRS affects more than a company's accounting policies, processes, and people. Ultimately, most aspects of a company's business and operations are affected potentially. Some of the business areas that pose challenge and need rearrangement in accounting policies and procedures under the new IFRS regime are:

\author{
1. Treasury management \\ 2. Distributions \\ 3. Debt covenants \& financing \\ 4. Mergers \& acquisitions \\ 5. Management \& employee compensation \\ 6. Potential tax implications \\ 7. Management information (MIS Reporting) \& Financial Forecasting \\ 8. Human resources \& training \\ 9. IT systems \\ 10. Investor relations
}

1. Treasury Management: Certain financing and hedging policies will no longer achieve the desired accounting effect but will instead create volatility in reported profits. Challenge is to have accounting policies that will produce right accounting treatment.

2. Distributions: Under IFRS, shareholder's equity might change and consequently the current dividend policy may no longer be sustainable. Altered dividend patterns may directly impact the share price.

3. Debt Covenants \& Financing: Re-negotiating contracts that referenced reporting accounting amounts, like bank covenants, will be required on convergence to IFRS. This might impact company's ability to ensure continuity of financing arrangements.

4. Mergers \& Acquisitions: Accounting for potential acquisitions will be altered by the adoption of IFRS and only purchase method will be followed. Goodwill will be capitalized and not amortized. Intangible assets need to be classified into indefinite useful lives category.

5. Management \& Employee Compensation: The amount of compensation calculated and paid under performance-based compensation scheme to the executives and employees under compensation plans may be materially different under IFRS because the company's financial results may be materially different.

6. Potential Tax Implications: Will the taxation laws realign itself to the definition of "taxable profits" calculated using IFRS accounting rules is the area of biggest concern for the industry. Valuation of assets will be on fair value basis. Both unrealized gains and loss will appear in profit and loss account. Change in the policy of Revenue recognition under IFRS regime.

7. Management Information (MIS Reporting): Forecasts and internal performance measurements may no longer be comparable with results reported in financial statements, making forecasting more difficult during initial years of IFRS adoption.

8. Human Resources \& Training: There is an urgent need of training throughout the organization and which is not limited only for finance/accounts department. Existing skills may not be adequate to tackle IFRS related issues. Need of internal IFRS skilled resource to maintain IFRS compliant IT systems.

9. IT Systems: Both, for internal and external reporting, the accounting and financial reporting systems need to be IFRS ready. It needs to have more data capture points and integrate with all the stand-alone finance/accounting modules for financial report generation.

10. Investor Relations: IFRS adoption may challenge the changes in profits and EPS. Investors will form their own expectation on new accounting policies and expect certain accounting outcomes. Need is to make investors understand the new set of financial statements under the IFRS regime.

\section{Benefits ahead with the convergence with IFRS}

There are many beneficiaries of convergence with IFRSs such as the economy, investors, and industry and accounting professionals.

\section{The Economy}

As the markets expand globally, the need for convergence increases. The convergence benefits the economy by increasing growth of its international business. It facilitates maintenance of orderly and efficient capital markets and also 
helps to increase the capital formation and thereby economic growth. It encourages international investing and thereby leads to more foreign capital flows to the country.

\section{Investors}

A strong case for convergence can be made from the viewpoint of the investors who wish to invest outside their own country. Investors want the information that is more relevant, reliable, timely and comparable across the jurisdictions. Financial statements prepared using a common set of accounting standards help investors better understand investment opportunities as opposed to financial statements prepared using a different set of national accounting standards. For better understanding of financial statements, global investors have to incur more cost in terms of the time and efforts to convert the financial statements so that they can confidently compare opportunities. Investors' confidence would be strong if accounting standards used are globally accepted. Convergence with IFRSs contributes to investors' understanding and confidence in high quality financial statements

\section{Industry}

A major force in the movement towards convergence has been the interest of the industry. The industry is able to raise capital from foreign markets at lower cost if it can create confidence in the minds of foreign investors that their financial statements comply with globally accepted accounting standards. With the diversity in accounting standards from country to country, enterprises which operate in different countries face a multitude of accounting requirements prevailing in the countries. The burden of financial reporting is lessened with convergence of accounting standards because it simplifies the process of preparing the individual and group financial statements and thereby reduces the costs of preparing the financia statements using different sets of accounting standards.

\section{The accounting professionals}

Convergence with IFRSs also benefits the accounting professionals in a way that they are able to sell their services as experts in different parts of the world. The thrust of the movement towards convergence has come mainly from accountants in public practice. It offers them more opportunities in any part of the world if same accounting practices prevail throughout the world. They are able to quote IFRSs to clients to give them backing for recommending certain ways of reporting. Also, for accounting professionals in industry as well as in practice, their mobility to work in different parts of the world increases.

\section{IFRS Implementation Challenges in India}

In spite of the various benefits of adopting IFRS, implementation of IFRS is a Herculean task in India. Following are a few challenging areas in adoption and implementation of IFRS in India:

\section{Creating awareness about international accounting practices:}

Adoption of IFRS means that the entire set of financial statements will be required to undergo a drastic change. There are a number of differences between the two GAAP's (discussed elsewhere in this paper). To make users to understand these IFRS compliant financial statements, it will require considerable effort in making them aware about core principles, practices and also the new vocabulary in IFRS.

\section{Availability of skilled staff:}

One of the challenges for the successful adoption of IFRS is the availability of experts, availability of academic courses on IFRS and inclusion of the key accounting policies/practices in curricula at graduate/post-graduate courses in Commerce Faculty in India. The permanent solution to this problem is that IFRS should be introduced as a full time subject and an area of specialization in all the universities in India.

\section{Amendments to existing Indian laws:}

Implementation of IFRS may result in a number of inconsistencies with the existing laws which include the Companies Act 1956, SEBI regulations, banking laws and regulations and the insurance laws and regulations. Currently, the reporting requirements are governed by various regulators in India and their provisions override other laws. IFRS does not recognize such overriding laws. The regulation bodies need to ensure that the laws are amended well in time to facilitate smooth adoption.

\section{Recognition of IFRS compliant financial statements by Taxation Laws:}

IFRS convergence would affect many of the items in the financial statements and consequently the tax liabilities would also undergo a change. Thus, the taxation laws and the thx authorities should ensure that there is clarity on the tax treatment arising on convergence from Indian GAAP to IFRS. It is extremely important that the taxation laws recognize IFRS compliant financial statements; otherwise it would duplicate compilation work for the organizations.

\section{Fair value measurement base:}

IFRS uses fair value as a measurement base for valuing most of the items of financial statements. The use of fair value accounting can bring a lot of volatility and subjectivity to the financial statements. It also involves a hard work in 
arriving at the fair value and services of valuation experts have to be used. Moreover, adjustments to fair value result in gains or losses which are reflected in the income statements.

\section{IFRS compliant financial accounting and reporting system(s):}

The disclosure and reporting requirements under IFRS are at great variance compared to Indian reporting requirements. Companies would have to ensure that the existing business reporting model and the Information Technology Systems used to collect financial data need realignment to suit the reporting requirements under IFRS. The information systems should be designed to capture the new data required statutory, regulatory and internal reporting purposes. Existence of proper internal control system and minimizing the risk of business disruption should be taken care of while modifying or changing these existing systems.

\section{Conclusion}

Though the shift from India GAAPs to IFRS is bit painful it is worth shifting because of the huge benefits which will be ripped by Indian Inc. The confidence of international investor will enhance and stock / scrip prices of Indian companies will be valued be valued correctly. The inflow of funds from Flls, and other international investor will accelerate and will help in bolstering Indian economy further. The professional bodies like ICAI, ICSI, ICWAI, will have more responsible role at international level and accounting professionals will get more global opportunities. So, to achieve long term goals, it is worthwhile to bear the pains of convergence.

\section{References}

1. Rajkumar S. Adukia, (2009), "Encyclopedia on IFRSs", Snow white Publication.

2. (2007), "Concept Paper on Convergence with IFRSs in India", The Institute of Chartered Accountants of India.

3. Jameel Khatri, Akhil Master (2009), "Convergence with International Financial Reporting Standards ('IFRS') Impact on fundamental accounting practices and regulatory framework in India", Bombay Chartered Accountant Journal, April 2009 (P. No. 71-74).

4. Buvanesh Sharma (2010), "IFRS - Challenges and Need for India Inc." http://www.indianmba.com/Articles on Management/AOM49/aom49.html

5. http://www.icai.org/www.sebi.gov.in

6. www.mca.gov.in

7. http://ifrs.acai.org

8. www.bseindia.com

9. www.nseindia.com

10. http://www.iasb.org

11. www.iasplus.com

12. http://en.wikipedia.org/wiki/International Financial Reporting Standards 